\title{
New insights into the neolithisation process in southwest Europe according to spatial density analysis from calibrated radiocarbon dates
}

\author{
Oreto García Puchol ${ }^{1}$ • Agustín Diez Castillo ${ }^{1} \cdot$ Salvador Pardo-Gordó $^{1}$ (D)
}

Received: 19 April 2016/Accepted: 20 April 2017

(C) Springer-Verlag Berlin Heidelberg 2017

\begin{abstract}
The agricultural way of life spreads throughout Europe via two main routes: the Danube corridor and the Mediterranean basin. Current archaeological literature describes the arrival to the Western Mediterranean as a rapid process which involves both demic and cultural models, and in this regard, the dispersal movement has been investigated using mathematical models, where the key factors are time and space. In this work, we have created a compilation of all available radiocarbon dates for the whole of Iberia, in order to draw a chronological series of maps to illustrate temporal and spatial patterns in the neolithisation process. The maps were prepared by calculating the calibrated $14 \mathrm{C}$ date probability density curves, as a proxy to show the spatial dynamics of the last hunter-gatherers and first farmers. Several scholars have pointed out problems linked with the variability of samples, such as the overrepresentation of some sites, the degree of regional research, the nature of the dated samples and above all the archaeological context, but we are confident that the selected dates, after applying some filters and statistical protocols, constitute a good way to approach settlement spatial patterns in Iberia at the time of the neolithisation process.
\end{abstract}

Keywords Radiocarbon dates $\cdot$ Neolithic $\cdot$ Mesolithic $\cdot$ Neolithisation · Iberian Peninsula

Electronic supplementary material The online version of this article (doi:10.1007/s12520-017-0498-1) contains supplementary material, which is available to authorized users.

Salvador Pardo-Gordó pargor@uv.es

1 Departament de Prehistòria, Arqueologia i Història Antiga, Universitat de València, Valencia, Spain

\section{Introduction}

Current data reveal that the neolithisation processes in Europe involves both demic and cultural mechanisms that reflect not well-explained patterns of human and cultural dispersals. In this sense, the spread of blades and trapezes in Europe was considered by Clark (1958) as a diffusion movement that precedes agro-pastoral expansion, although not developed studies have linked this phenomenon in an integrate framework (Binder et al. 2012). Major attention has been focused on the emergence of agriculture as one of the most important developments in the history of humanity, due to its socio-economic implications and its vital role in the formation of complex societies. The hypothesis sustained by Childe (1925), that the European Neolithic was brought about by the migration of farming groups originating in the Near East, has long since been demonstrated through many archaeological evidence including the absence of wild ancestors of documented domestic plants and animals during the early Holocene (Colledge and Conolly 2001) and corroborated by DNA studies (Larson and Burger 2013) and previously by computational simulation (Ammerman and Cavalli-Sforza 1984). Although the majority of the available evidence indicates a process of migration of the first agriculturalists (Pinhasi et al. 2005; Bocquet-Appel et al. 2012; Mathieson et al. 2015; Olalde et al. 2015; Hofmanová et al. 2015), the debate is far from closed, and the Iberian Peninsula serves as an excellent example relating to this subject (Zilhão 2011; Bernabeu et al. 2015a; Pardo Gordó et al. 2015 Isern et al. 2017).

The spread of the first farmers has been investigated by means of mathematical models (see Fort 2015 for a complete list of references) where time (as shown in radiocarbon dates) and space (the sites) are the key factors. This interest in radiocarbon has given rise to an increase in radiometric information in the last decade, with numerous databases produced on a 
European scale (Davison et al. 2009; Shennan et al. 2013; Manning et al. 2016) as well as some focused on smaller areas such as the Western Mediterranean or Iberia (Sabatier and Manen 2003; Bernabeu et al. 2014; Isern et al. 2014; Balsera et al. 2015a; Balsera et al. 2015b).

Our goal in this paper is mapping the neolithisation process in Iberia by collecting and filtering all the available radiocarbon information, from the last Mesolithic and the Early Neolithic, based on a longue durée vision. To that end, we emphasise the analysis of the nature of the samples and their geographical distribution in accordance with spatial radiocarbon density distributions (Collard et al. 2010). In previous works, some of the problems we are going to tackle have been treated through modelisation (Pardo Gordó et al. 2015), but our focus here is to look at the geographical dispersion of the phenomena under study in new ways from radiocarbon dates through maps (García Puchol et al. 2016) and summed calibrated date probability distributions (SCDPD) (built from dates and dated sites) including certain filters and factor corrections. In the following paragraphs, we will concentrate on discussing the spatial distribution patterns of the last Mesolithic and the emergence of the Neolithic and its expansion in the light of the radiometric information.

\section{Regional setting}

From the first centuries of the 7th millennium cal BC and coinciding with the beginning of the Atlantic period, late Mesolithic techno-complexes in Western Mediterranean are characterised by the irruption of blade technology and trapezes throughout the region (Binder et al. 2012). This major phenomenon implies explanations that encompass hypothesis of cultural and/or some kind of demic movements (Marchand and Perrin 2015). In Iberia, blade technology and trapezes (Geometric Mesolithic) are recognised in different areas of the Mediterranean basin (Martí Oliver et al. 2009), the Ebro valley (Utrilla et al. 2009) and the south Atlantic coast of Portugal (Carvalho 2009; Bicho et al. 2011). These blade complexes present a substantial change if we compare them with previous lithic assemblages characterised by notched and denticulate tools on flakes. The introduction of regular blade knapped techniques along the region indicates at least the spread of information through a wide area that includes the Western Mediterranean zone. While only a few works reflect the interest to explore these mechanisms (Binder et al. 2012; Clark 1958, Marchand and Perrin 2015), some try to put their attention on the origins of blade techniques and trapezes referring the possibility of a north African origin (Marchand and Perrin 2015).

Generally speaking, most researchers coincide in the importance of a demic diffusion model in the spread of agro-pastoral economies through Western Mediterranean territories (Guilaine 2001; Zilhão 2001; Guilaine and Manen 2007; Bernabeu and Martí Oliver 2014; Guilaine 2014). In this sense, J. Zilhao (2001) suggests a pioneer movement along the coast reflecting to explain the somewhat fast spread of the Neolithic. J. Guilaine (2001) describes a noncontinuous model, so-called arrythmic model, on a spatial and temporal scale. At the same time, some other authors incline towards a cultural transmission process through Mesolithic networks (Vicent García 1997; Díaz del Río Español 2011; Cruz Berrocal 2012). A mixed model has been proposed in the Valencia region (Eastern Iberia) that assumes the arrival of Neolithic pioneers and describes the possibilities of interaction with local hunter-gatherers (Juan Cabanilles and Martí Oliver 2002; Juan Cabanilles and Martí 2011; Bernabeu and Martí Oliver 2014).

The agricultural way of life appears in the south-eastern area of the Italian peninsula (Apulia) at the end of the 7th millennium cal BC linked with the so-called impressed ware culture. The first farmers and herders in the Iberian Peninsula appear earlier along the Mediterranean coast and some inland areas (Ebro valley). Current research points out the recognition of a major diversity in the first ceramic styles, represented mainly by the Cardial tradition (Bernabeu and Martí Oliver 2014). In the Eastern region, some similarities with the early impressed ware tradition described in Southern France have been noted - notably at the sites of El Barranquet in Valencia and Mas d'Is in Alicante - at the middle of the 6th millennium cal BC (Bernabeu et al. 2009). In contrast to the scarcity of late Mesolithic settlements noted in Italy and Southern France, Iberia shows a great variety of situations over the different areas considered. The discussion about the existence of contacts between Mesolithic and Neolithic groups and their role in the neolithisation process remains open.

\section{Materials and methods}

In order to approach the temporal spatial distribution of the last hunter-gatherers and first farmer settlements, we have compiled a total of 1276 radiocarbon dates (Table 1) spanning from 8000 to $5500 \mathrm{BP}$ (circa 7400 to $4400 \mathrm{cal} \mathrm{BC}$ ) from a variety of publications including works of synthesis, grey literature, monographs and both continental (from European projects such as the formation of Europe: prehistoric population dynamics and the roots of socio-cultural diversity (FEPRE)) and regional databases (Juan Cabanilles and Martí Oliver 2002; Sabatier and Manen 2003; García Puchol 2005; Bernabeu 2006; Cubas Morera and Fano 2011; Rojo Guerra et al. 2012; Balsera et al. 2015a and b; Catalunya C14: http://www.telearchaeology.com) , as well as a considerable number of recent papers on the subject (Vergès Bosch et al. 2008; Martí Oliver 2011; García Borja et al. 2012; Aura Tortosa et al. 2013; Medved 2013; Cebrià i Escuer et al. 2014; Oms et al. 2014; Gibaja et al. 
Table 1 List of radiocarbon dates of the Iberian Peninsula (between 8000 and $5000 \mathrm{BP}$ ) depending on the nature of the sample and its location in response to the region concerned. The number of dates used to draw maps, the number of sites with dating in different regions and the average standard deviation

\begin{tabular}{|c|c|c|c|c|c|c|c|c|c|c|c|c|}
\hline & Iberia & Northern & $\begin{array}{l}\text { U/M } \\
\text { Ebro }\end{array}$ & $\begin{array}{l}\text { U/M } \\
\text { Douro }\end{array}$ & Cantabria & Galicia & $\begin{array}{l}\text { U/M } \\
\text { Tagus }\end{array}$ & $\begin{array}{l}\text { East/ } \\
\text { southern }\end{array}$ & $\begin{array}{l}\text { South } \\
\text { Mediterranean }\end{array}$ & $\begin{array}{l}\mathrm{U} / \mathrm{M} \\
\text { Guadiana } \\
\text { Guadalquivir }\end{array}$ & $\begin{array}{l}\text { L. Guadiana/ } \\
\text { Guadalquivir }\end{array}$ & Portugal \\
\hline Radiocarbon dates & 1275 & 173 & 195 & 60 & 149 & 30 & 38 & 205 & 71 & 77 & 22 & 246 \\
\hline Sites & 347 & 61 & 34 & 17 & 56 & 22 & 18 & 48 & 11 & 10 & 10 & 67 \\
\hline Charcoal & 545 & 92 & 79 & 42 & 87 & 21 & 21 & 63 & 27 & 24 & 5 & 66 \\
\hline $\begin{array}{l}\text { Charcoal } \\
\text { (short taxa) }\end{array}$ & 18 & 6 & 3 & 0 & 0 & 0 & 2 & 2 & 1 & 0 & 0 & 4 \\
\hline Total bones & 414 & 46 & 95 & 8 & 39 & 0 & 14 & 85 & 18 & 13 & 2 & 95 \\
\hline Domestics & 79 & 14 & 10 & 1 & 1 & 0 & 3 & 19 & 15 & 7 & 0 & 8 \\
\hline Human & 154 & 18 & 20 & 3 & 17 & 0 & 7 & 29 & 2 & 3 & 1 & 54 \\
\hline Seed/fruits & 131 & 23 & 15 & 10 & 3 & 0 & 1 & 27 & 8 & 36 & 0 & 1 \\
\hline Wheat/barley & 95 & 16 & 14 & 8 & 1 & 0 & 1 & 16 & 8 & 31 & 0 & 0 \\
\hline Shell & 112 & 0 & 0 & 0 & 18 & 0 & 0 & 6 & 0 & 4 & 5 & 79 \\
\hline Other & 22 & 1 & 0 & 1 & 0 & 8 & 0 & 7 & 4 & 0 & 0 & 1 \\
\hline Indeterminate & 33 & 5 & 3 & 0 & 1 & 3 & 1 & 1 & 8 & 0 & 10 & 0 \\
\hline Radiocarbon select & 834 & 101 & 168 & 27 & 74 & 10 & 32 & 164 & 57 & 62 & 4 & 135 \\
\hline Sites & 239 & 38 & 30 & 9 & 35 & 9 & 14 & 40 & 10 & 4 & 2 & 46 \\
\hline Standard deviation & 59.9 & 62 & 52.6 & 59.4 & 66.4 & 60.7 & 48.8 & 59.45 & 58.4 & 62.7 & 117.5 & 64.4 \\
\hline
\end{tabular}

$U / M$ upper/middle, $L$ lower

2015). We have audited all radiocarbon dates in accordance with the contexts dated in order to increase the quality of our radiocarbon dataset.

The chronological interval considered covers around three millennia, from the last hunter-gatherer populations, including the end of the Mesolithic with notches and denticulates tools; the irruption and development of the last Mesolithic; the Mesolithic with blade technology and trapezes, from 6800/ $6600 \mathrm{cal} \mathrm{BC}$; and the first Neolithic settlements (Cardial/ Impressa ware culture), from circa $5600 \mathrm{cal} \mathrm{BC}$. For practical purposes, the database has been divided into seven geographical areas spread throughout the territory according to the main water basins and coastal areas, as shown in Fig. 1. The dates have been classified by sample materials to remark the differences related to the specific weight of certain of them in each of the regions (Table 1).

In this work, following previous papers focused on radiocarbon analysis (Bernabeu et al. 2014 and 2015b), we use radiocarbon dates to illustrate the spatial density of calibrated probabilities. The method is similar to summed probabilities of calibrated dates (SCDPD), so that we assume that variation exhibited across space and time can be useful to explore diachronic trends in human settlement according to the temporal slides produced. The method has been improved in several analyses testing the observed regional datasets with simulated date distributions under a fitted null model (Shennan et al. 2013) and considering taphonomic bias (see Surovell et al. 2009) and recently including the false positive remover function (Downey et al. 2014). Despite the uncertainty surrounding these methods in connection with the evaluation of human settlement (Contreras and Meadows 2014, Torfing 2015), we concur with other authors in considering this as a useful tool for observing general tendencies (Shennan et al. 2013). Recently, there has been a notable increase in the use of summed probabilities of calibrated dates, as an efficient way of taking a panoramic view of historical processes, that it serves more specifically as an approximate demographic indicator (Gamble et al. 2005; Timpson et al. 2014; Timpson et al. 2015; Pettitt and Zilhão 2015; Balsera et al. 2015b; Downey et al. 2016; Drake et al. 2016).

At the same time, several researchers (Zilhão 2001) have become aware of the problems linked with samples nature advocating for the need to date samples directly related to the event under investigation: which in the case of the Neolithic are almost exclusively domestic remains (cereal grains and sheep and goat bones). Nonetheless, in many instances, the use of radiometric information has not been qualified by a careful scrutiny of the samples in question, as well as their archaeological context, although such a process seems essential to validate the results. In various works, different problems associated with radiocarbon dates which affect our reading of the archaeological record have been highlighted (Martins et al. 2015; Wood 2015). A further point is that the application of the 'reservoir' effect on marine samples also presents problems, as this effect fluctuates both temporally and geographically 
Fig. 1 Map of Iberia with indication of the regions considered in this work

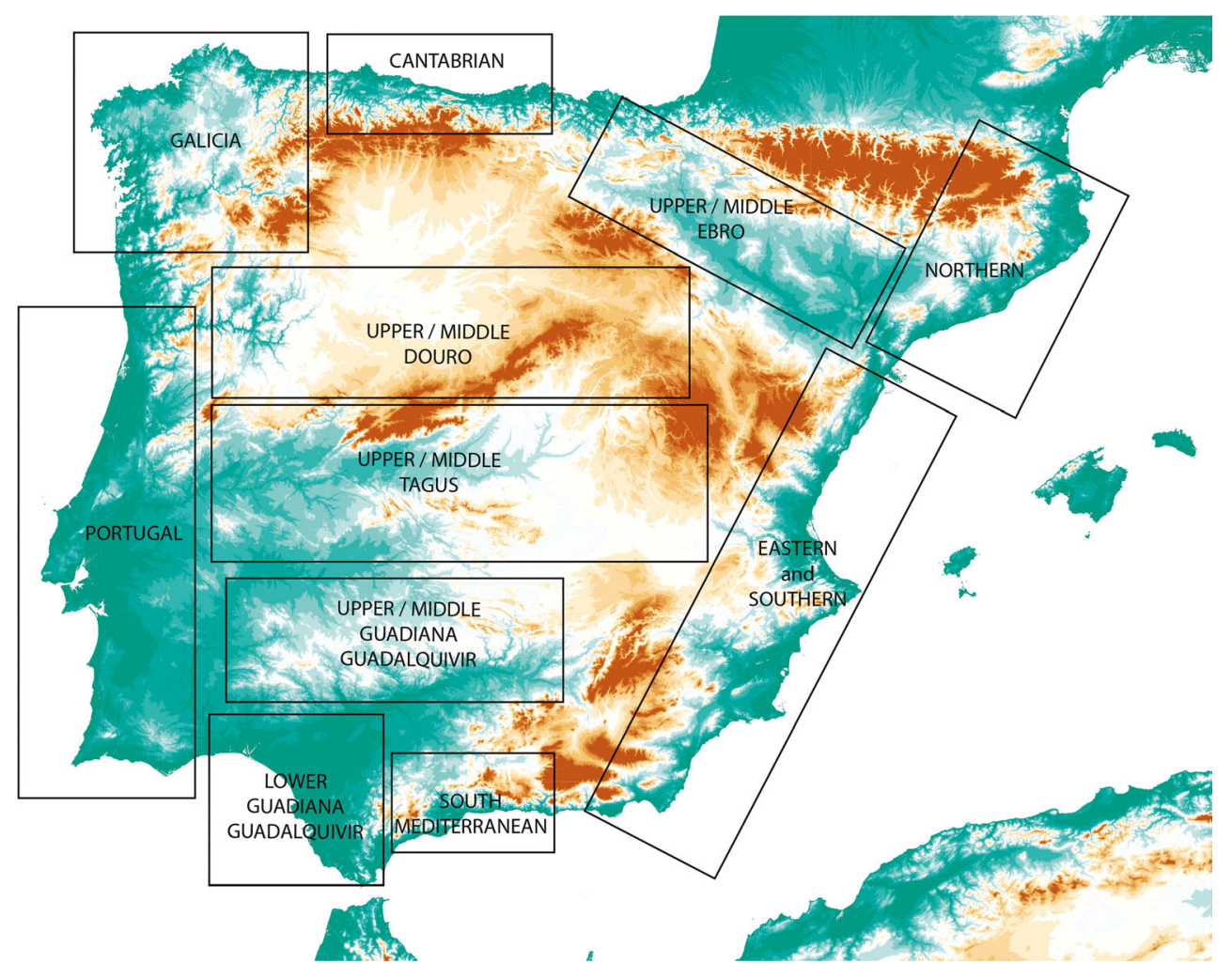

(Ascough et al. 2005), and although a correction factor can be applied, a considerable variation still exists (Soares and Dias 2006). We should also highlight some problems related to bone samples: more specifically, whether or not particular methods of ultrafiltration are used to control the quality of the collagen (Motuzaite-Matuzeviciute et al. 2015; Wood 2015), as well as problems related to the use of bones affected by fire, similar to the old wood effect (Olsen et al. 2013). Finally, dates of domestic samples are not without problems, in particular those associated with distinguishing some domestic species (animal or plant) from their wild counterparts: although the application of protein analysis (Martins et al. 2015) seems to be a valid method for solving this problem in the near future.

Starting from these premises, we have applied different filters in order to increase the reliability of our sample selection, always keeping in mind that the geographical size of our study area (Iberia) reduces those negative effects. The first filter consists of ruling out all those dates that could be unpredictably affected by the reservoir effect (marine shells and human bones). Secondly, we have selected radiocarbon dates with a standard deviation of less than 150 years considering prior analyses of the temporal variability of the sum of probabilities which suggest that representativeness depends on the sample size, which in turn is related to the average standard deviation of the dates and the time length of the analysed period (Williams 2012).

After applying both filters, we have a total of 834 dates coming from 239 sites (the SD average of the selected set is
59.9). As can be seen in Fig. 2, the distribution by site is completely uneven, ranging from sites with more than 30 dates to as many as 119 sites with only a single date. Once the selected set was obtained, a series of calculations were carried out on the selected radiometric information with the help of some R packages (Core Team 2013). The dates were calibrated with the Bchron package (Parnell 2014) using the calibration curve IntCal13 (Reimer et al. 2013). The summed probabilities of each dating are grouped by 200 -year periods (from the 7800-7601 cal BC interval backwards to the 5000 4800 cal BC one), and this variable is grouped by site and the probabilities of each of them are summed. In order to obtain homogeneous information for each interval, the sum obtained at each site in a chronological period is standardised to one (Wickhman 2014). Those point values are then interpolated applying a smoothed Gaussian isotropic kernel (Diggle 1985; Badeley and Turner 2005; Baddeley et al. 2015) with a value of $50 \mathrm{~km}$ via the density.ppp command from the spatstat package (Badeley and Turner 2005). We have considered other kernel values but discarded them because they mask some of the regional nuances that were part of our prior assumptions. In our opinion, beyond the research bias in favour of some areas (Valencia region, Catalonia, Madrid area, Cantabrian fringe), there are differences in the total population of some other areas (i.e. Guadiana valley, Galicia) where enough archaeological research has been undertaken in recent years, showing that the neolithisation process had important differences within the Iberian Peninsula which both we and other 


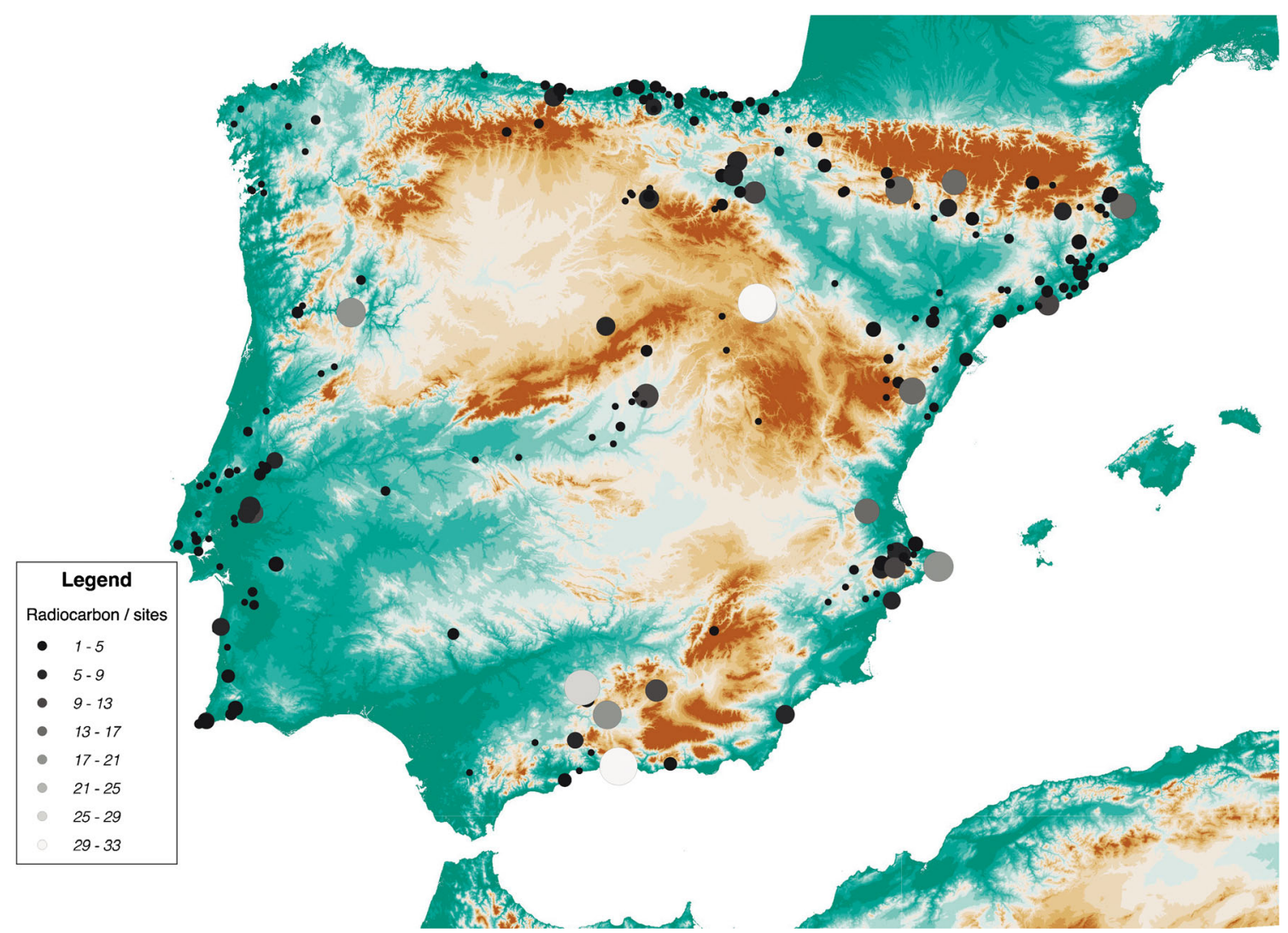

Fig. 2 Spatial and quantitative distribution of radiocarbon dates

authors have remarked (Juan Cabanilles and Martí Oliver 2002; Utrilla et al. 2009; Bernabeu et al. 2014). We are well aware that it could be argued that 834 dates are too little for the whole Iberian Peninsula and a span period of almost 3000 years, but the fact that dates and sites are taken into consideration in 200-year slices makes sites and dates per period more consistent with an average of 65.7 for the dates and 24.6 for the sites in each period. Eventually, each of the images obtained from the interpolation process (Badeley and Turner 2005), in order to be printed with rasterVis (Perpinan and Hijmans 2014), is converted to a raster object within the raster package (Hijmans 2015). The whole procedure allows a spatial representation (maps) of the density of the radiocarbon dates (see also Collard et al. 2010), facilitating a diachronic reading of the population dynamics of the last huntergatherers and first agricultural groups in Iberia.

\section{Results}

With the purpose of exploring settlement dynamics since the end of the Mesolithic to the introduction and consolidation of the Neolithic, summed calibrated date probability distributions (SCDPD) have been elaborated for both periods together as well as separately, to observe general tendencies (Fig. 3) in the updated radiocarbon database, in accordance with previous works (Bernabeu et al. 2014 and 2015b). Figure 4 presents audited radiocarbon dates and sites dated by interval before and after applying the Surovell equation, which considers taphonomic bias (Surovell et al. 2009). As explained above, we assume that the filters applied reduce certain biases that could affect the method. Both series of graphs (if we ignore the tails on each of the curves that are the result of our chronological limits) allow us to point out some interesting questions relating to the trends of relative settlement dynamics:

a) Coinciding with the arrival of blade and trapeze industries, the graphic shows a moderate increase in radiocarbon dates.

b) The Mesolithic probability sum presents a drastic reduction around $5600 \mathrm{cal} \mathrm{BC}$, although the calibration curve associated with hunter-gatherer sites lasts until circa $4500 \mathrm{cal} \mathrm{BC}$.

c) The behaviour of the calibration associated with the Neolithic (blue) presents two main points of emergence: the first is situated circa $6000 \mathrm{cal} \mathrm{BC}$, where the accumulated density is 0.1 , and the second considerable density increase is located in 5600 , where the accumulation is 0.2 .

Figure 5 shows the maps which result from the insertion of the date densities in intervals of 200 years between 7400 and $4200 \mathrm{cal} \mathrm{BC}$. In this first mapping, we have included both long- and short-life dates, coming from either single samples or 


\section{Summed radiocarbon probability distributions}

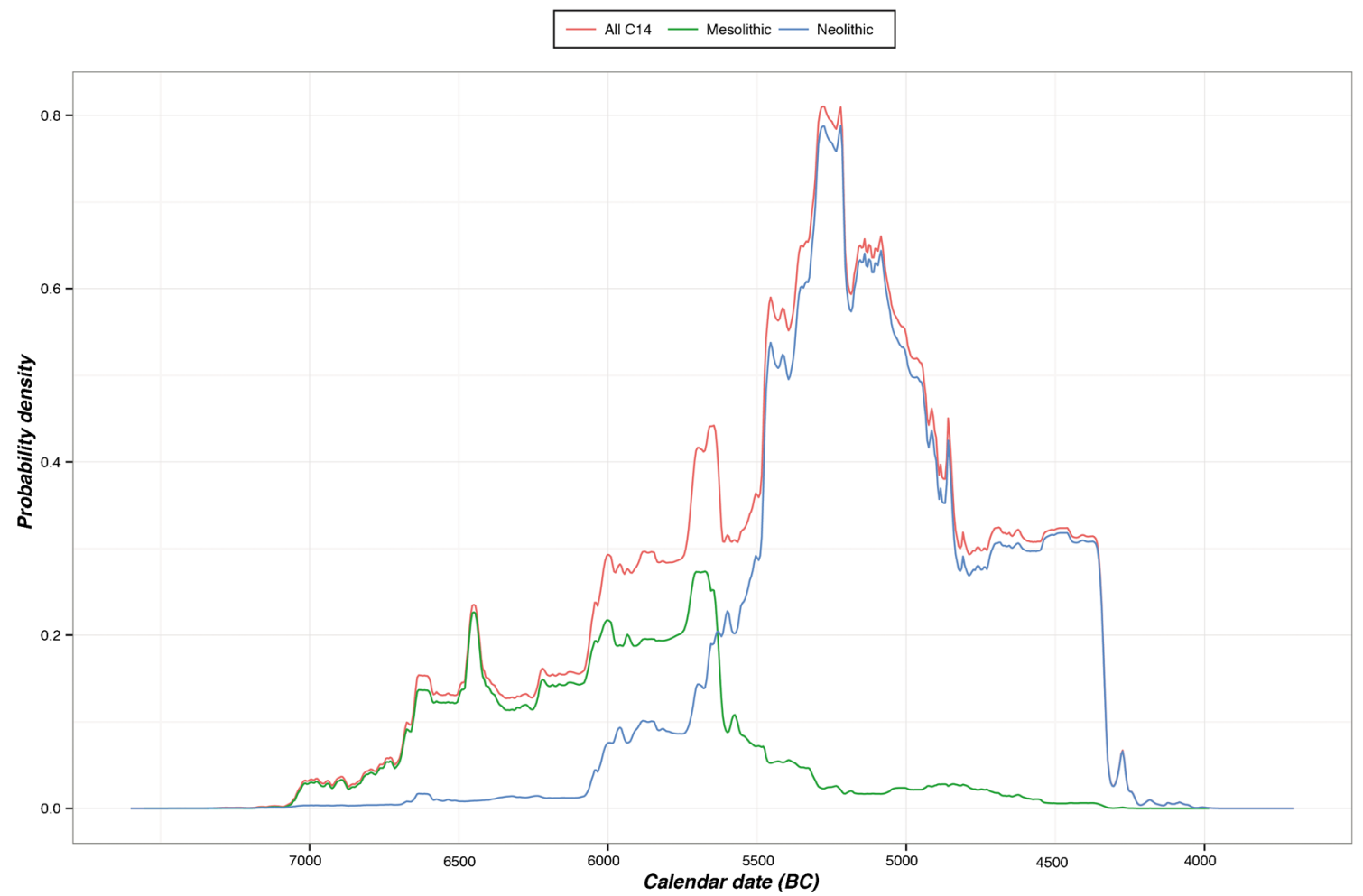

Fig. 3 Red line: a SCDPD of Iberian radiocarbon dates between 7400 to 4200 cal BC. Green line: Mesolithic radiocarbon dates. Blue line: Neolithic radiocarbon dates

grouped ones. We note that some outliers can appear related to the variables employed, specially in the readings of the periods 7200-7000 and 4200-4000 cal BC, which should be interpreted with caution. The observed trend in these graphs is the same as in Figs. 3 and 4: an increase with the passage of time in the number of sites with radiometric information. If we focus on Fig. 5 (below maps), which corresponds to the graph of the Mesolithic sites, we should point out the concentration of dated sites in the East of the peninsula, the Ebro valley, the Cantabrian region and the Portuguese area around the Tajo estuary (in particular the Muge shell middens). Also, as has been emphasised in the literature, there are large areas (e.g. Northwestern and Centre) where we lack this kind of information (Juan Cabanilles and Martí Oliver 2002; Utrilla et al. 2009; Bernabeu et al. 2014): a situation which should not be associated with problems of bias but rather with the dynamic of settlement itself, at the start of the Holocene period. Coinciding with the end of the Mesolithic with notches and denticulates tools, the concentration of dates corresponds with the Mediterranean coast and the Upper and Middle Ebro valley. The arrival of blade and trapeze industries (Geometric Mesolithic) is documented in the map interval (6600-6400 cal BC) where we can observe a decrease in density in Northeastern of Iberia while in Eastern Iberia and the Ebro valley territories, the tendency is maintained.
The major shift has been detected in the interval post 8.2 cal BP ky event (6000-5800 cal BC) where the eastern coast presents a retreat of the radiocarbon densities. Looking at Fig. 5 (upper maps), we notice a clear change of tendency, and in the interval 5800-5600 cal BC, the first dates in the interior of the peninsula are observed, but overall since 5600-5400 cal BC on, there is an increase in dates associated with Neolithic sites in the east, the south (Malaga area) and the Meseta. This tendency remains constant, and although in the 4800-4600 interval it diminishes, it recovers again rapidly (4600-4400 cal BC).

In order to discuss with more detail the neolithisation of Iberia, we have elaborated a new series of graphs focusing on the chronological period 6000-4800 cal BC and employing only those dates carried out on specific Neolithic evidence: which means mapping the dates taken from domestic samples (Fig. 6). Due to the reduced sample considered now, we consider the results only illustrative of spatial tendencies in the advance of domestic remains through Iberia.

In Fig. 6, all domestic samples (animals and seeds) have been represented without distinction in the 6000 5800 cal BC period. We can observe the single appearance of the Carigüela site in southern Iberia. In the next interval (5800-5600 cal BC), various isolated points can 

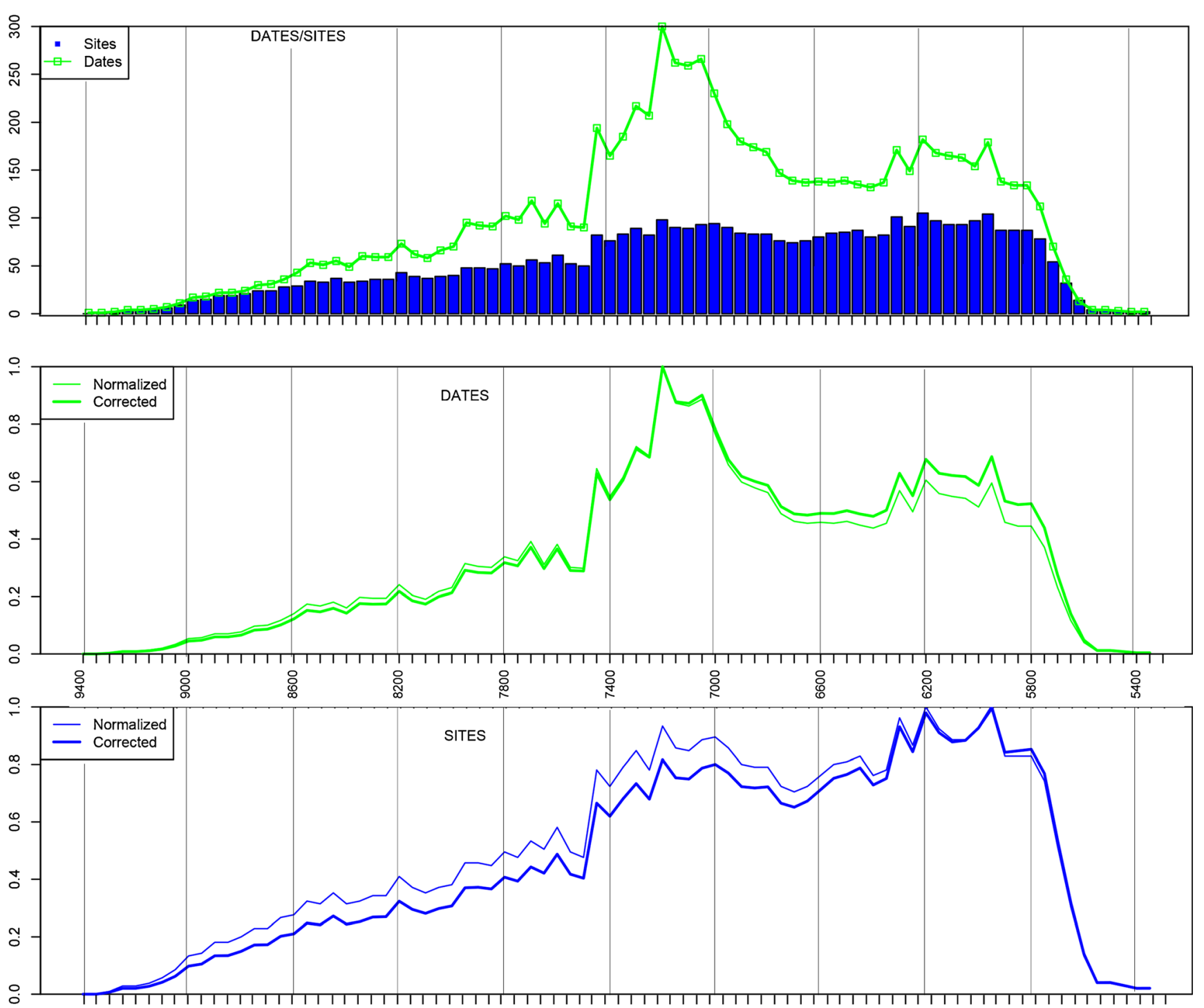

Fig. 4 From top to bottom, number of sites and dates per interval, number of dates normalised to 1 (fine green line) and corrected after Surovell et al. (2009) (coarse green line), and number of sites normalised to 1 (fine blue line) and corrected after Surovell et al. (2009) (coarse blue line)

be observed in the centre of the peninsula, plus three important concentrations of radiocarbon densities in Catalonia, in the central-southern areas of the Valencian region and on the coast of Malaga. In the following interval, we see an increase in density dates (considering only domestic dates) in the aforementioned areas, plus a first appearance of domestic samples in Portugal. The next map (5400-5200 cal BC) shows a significant increase in the number of sites with domestic dates throughout the territory, with notable absences in the north-east of the peninsula and a large part of the Cantabrian coast. This vacuum continues in the ensuing ones and it also noticeable in the maps showing all the sites with radiometric information (Fig. 5).

Nonetheless, if we analyse the emergence of the Neolithic using only the dates taken from cereals- avoiding in this way controversial identifications of domestic bones (Martins et al. 2015) —we got a different picture (Fig. 7). The distribution of domestic cereals reveals, in the 5800-5600 interval, a concentration in two areas of the Mediterranean area (the Llobregat area on the Catalonian coast and Serpis valleys in the Valencian region), as is the case also in the following period. As can be seen in both maps, a single site is located in the Meseta area: La Paleta, a site with storage pits that provides a date taken from Cerealia sp. embedded in a ceramic container (Jiménez Guijarro et al. 2008). Finally, in the 54005200 cal BC interval an increase in densities in the original areas (Catalonia and Valencia), as well as new locations in the inland (Meseta) and south of the peninsula can be observed. In this respect, if we compare the aforementioned interval in both map series (Figs. 6 and 7), the rapid 
Fig. 5 Iberian Peninsula density maps since 7400 to $4200 \mathrm{cal} \mathrm{BC}$
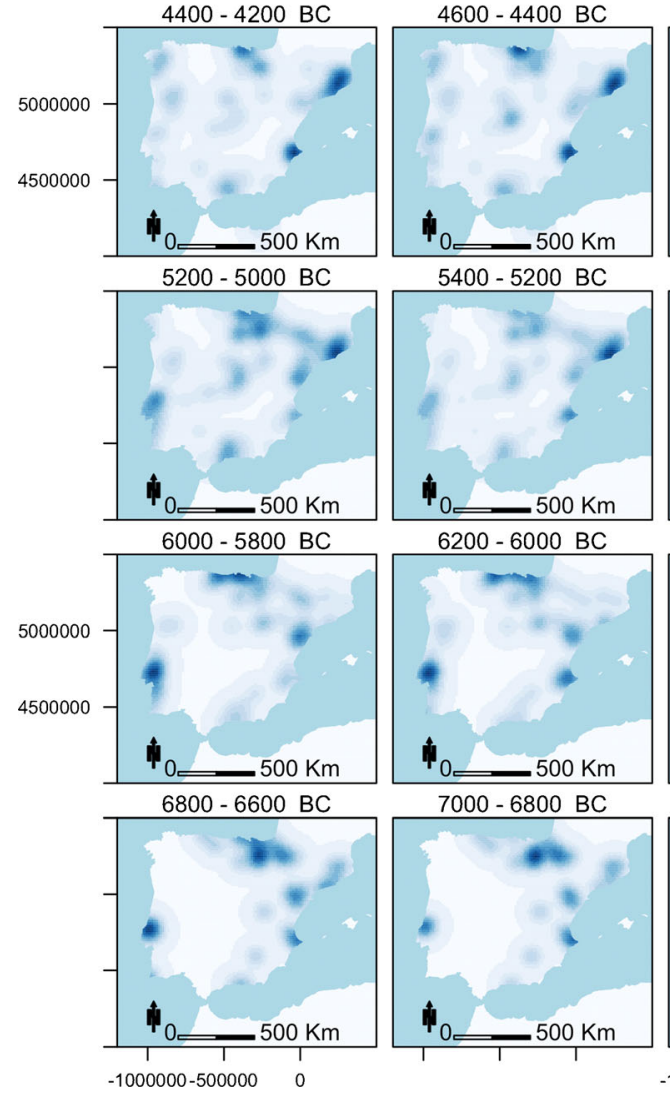

$6200-6000 \mathrm{BC}$

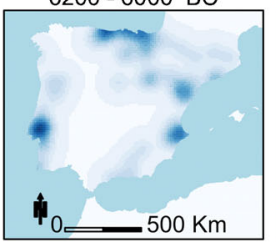

$7000-6800 \mathrm{BC}$

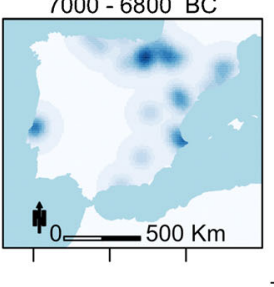

$4800-4600 B C$
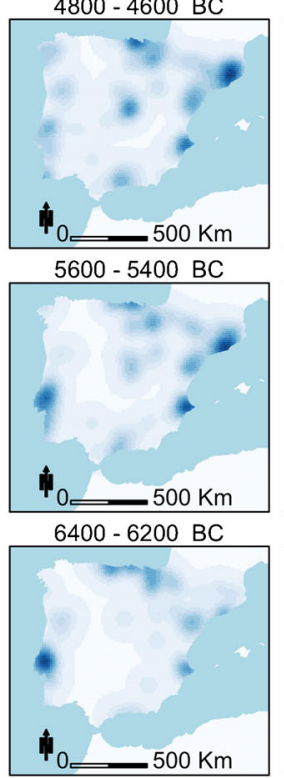

$7200-7000 \mathrm{BC}$

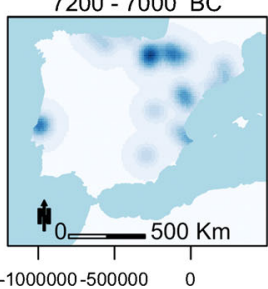

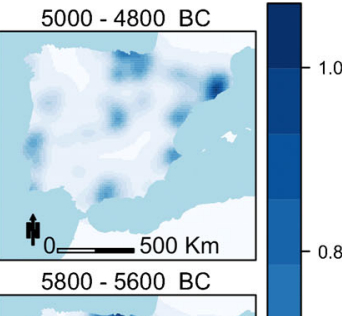
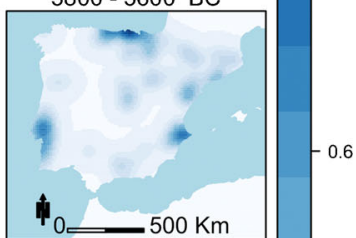

$6600-6400 \mathrm{BC}$

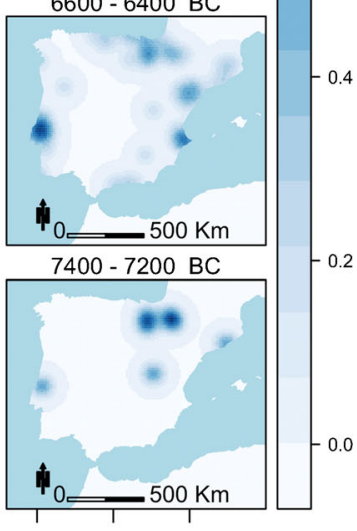

Neolithic spread towards the Cantabrian and Atlantic Iberian coasts seems to be less evident in the cereal-based graphs than in those based on domestic bones.

\section{Discussion}

In this work, we have sought to update the cartography of the neolithisation process in Iberia. In our mapping, we have included the moments prior to this process, which cover the end of the notches-denticulates tools complex and the development of the last Mesolithic one (including blade technology and trapeze complex in the Mediterranean territories and in centralsouthern Portugal within a Castelnovian tradition (Binder et al. 2012; Utrilla et al. 2009) and the Mesolithic with geometrics in the Cantabrian region (Arias Cabal and Fano 2009). Focusing on the appearance of blade and trapeze industries, a general East/West route can be suggested, although if we consider the general radiocarbon density maps, some problems persist according to the regional absences detected. We should emphasise that both maps and the sum of probabilities indicate a gradual increase in radiocarbon dates, as from $7000 \mathrm{cal} \mathrm{BC}$, following a pattern which is similar in the Mediterranean region (from the south of the Ebro to the coast of Malaga), the Cantabrian coast, the main estuaries in Portugal and the Ebro valley. This pattern persists until the $5800-5600 \mathrm{cal} \mathrm{BC}$ interval, when a notable drop in the number of dated sites occurs, although in the following period, there is a notable increase in the density of sites dated. This inflection is of special interest because it coincides with the emergence of the first domestic dates.

If we analyse the moments prior to neolithisation, a number of works have explored the territorial patterns of the last huntergatherers and their relationship to climatic fluctuations, in particular the 8.2 event (6200 cal BC) (Weninger et al. 2006; Berger and Guilaine 2009; Fernández López de Pablo and Gómez Puche 2009; González-Sampériz et al. 2009; Gronenborn 2009; Cortés Sánchez et al. 2012; Bernabeu et al. 2014; García Puchol et al. 2015). Our cartography does not reflect significant differences regarding this climatic event, and, as some of us have mentioned elsewhere (Bernabeu et al. 2014), only a regional and sub-regional analysis would permit a more suitable evaluation of any possible population-climate connection. Nonetheless, a detailed analysis of our maps allows us to observe certain aspects of the last Mesolithic and early Neolithic settlement patterns. On one hand, we have the NorthEast Iberia area, with its total absence (to date) of Late Mesolithic archaeological information (Vaquero Rodríguez and García-Argüelles 2009). This is clearly shown in our cartography where the 6600 to $5800 \mathrm{cal} \mathrm{BC}$ time span confirms the absence of Mesolithic population. On the other hand, we have the Valencia district (Serpis valley, mainly) where the absence of Mesolithic sites since the beginning of the sixth millenium 

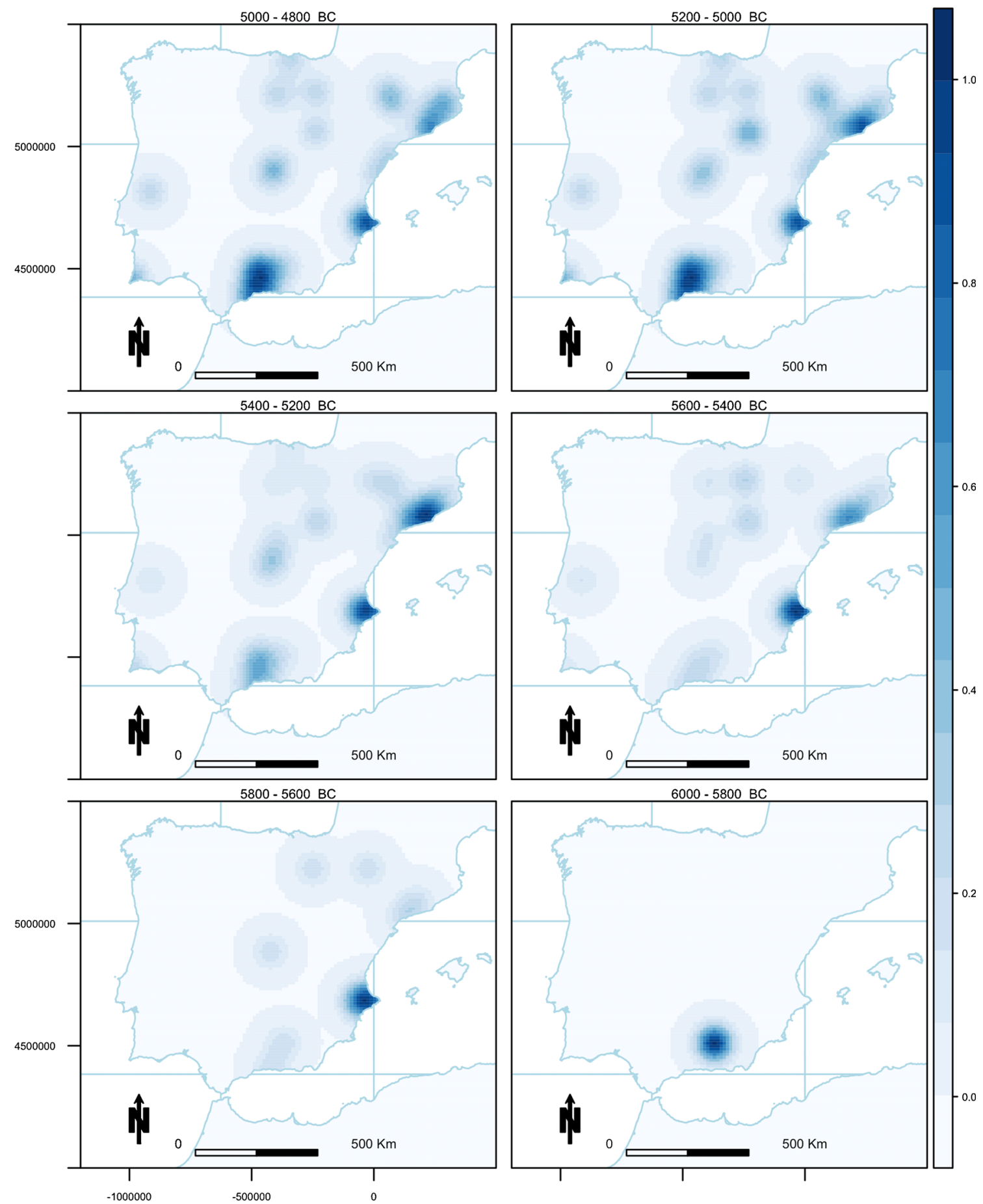

Fig. 6 Iberian Peninsula density maps since 6000 to 4800 cal BC (only Neolithic items)

cal $\mathrm{BC}$ is well documented, yet with a clear cartographic sign of neolithisation in the 5800-5600 cal BC interval (García Puchol and Aura Tortosa 2006; García Puchol et al. 2009; Torregrosa Giménez et al. 2011; Bernabeu et al. 2014; Jover Maestre and García Atienzar 2014).

Current debate about the Neolithic spread in Iberia focuses on two main subjects relating to the expansion models: cultural diffusion (Vicent García 1997; Díaz del Río Español 2011;
Cruz Berrocal 2012) versus a demic explanation that encompasses mixed models (Zilhão 2001; Isern et al. 2014) and the possible routes of the introduction of the first farming groups (Manen et al. 2007; García Borja et al. 2014; Isern et al. 2014).

Regarding the first question, it is beyond doubt that the Neolithic expansion in Iberia took place across a territory with a prior Mesolithic population, although, as seen in the graphs (Fig. 4), this was unevenly distributed across the territory. In 

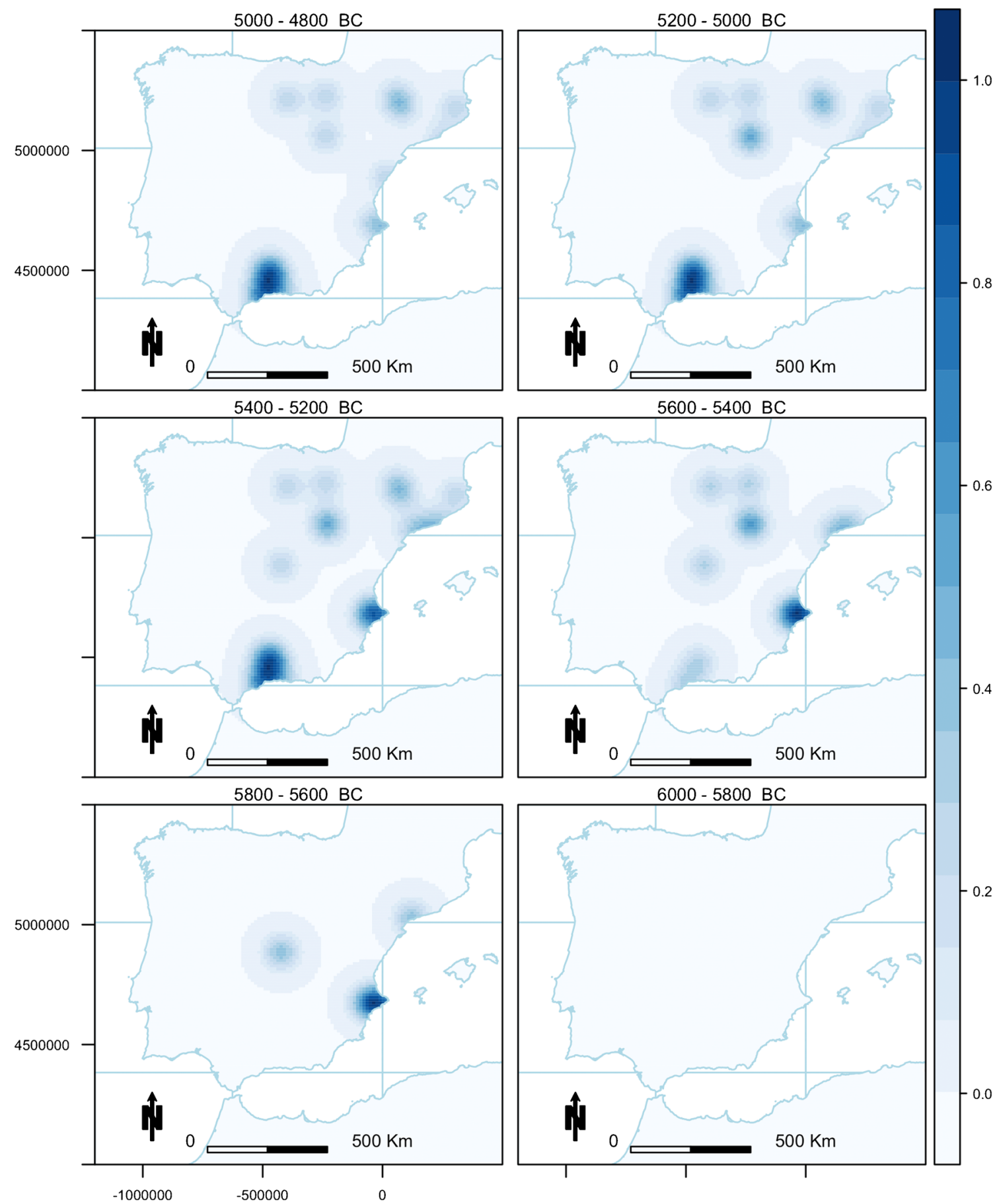

Fig. 7 Iberian Peninsula density maps since 6000 to 4800 cal BC (only cereals)

this regard, it is worth noting that the first Neolithic groups settle in areas which, at the time of the farmers' arrival, seem to be uninhabited $(6000-5800 \mathrm{cal} \mathrm{BC})$ : Catalonia, mid and south Valencia districts and the coast of Malaga. Other areas such as Ebro and Portugal show a similar pattern in a more recent chronological interval, as does the Meseta. An initial demic impact is sustained in accordance with current data from ancient DNA obtained in Mesolithic and Neolithic human skeletons (Olalde et al. 2015).
Also, there can be no doubt regarding the East-West expansion, although we can observe a few discrepancies: Carigüela, a Neolithic Cardial site located in the south (Granada: Medved 2013), and La Paleta in Central Iberia (Jiménez Guijarro 2010). In our view, the radiocarbon dates of Carigüela, at least, open the question about the scarce archaeological information available and the possibility of problems linked with bone dates (Wood 2015; Martins et al. 2015). We should remember that maps from cereals do not reflect this ancient impact in 
southern Iberia according to the current radiocarbon dataset. The problem linked with the date of La Paleta (pit 210) is a specific case and due to its geographical isolation should be re-evaluated. Leaving these discrepancies aside, the neolithisation cartography shows the importance of coast and the Ebro river as the main routes of expansion for the agriculturalist way of life; at the same time, the domestic advance in the second half of the 6th millennium cal $\mathrm{BC}$ seems restricted to a limited territorial pattern.

Another recurrent issue in the neolithisation literature is the debate surrounding the routes of the Neolithic expansion. In recent years, debate has reopened regarding the possibility of a dual Mediterranean route: a northern one through the Gulf of Genoa and the Côte d'Azur and southern one through the Maghreb coast. With regard to the Northern route (the Gulf of Genoa), a ceramic impresso horizon has recently been documented in the Valencian region, which appears to have similarities to the impresso-ligur ceramics identified in sites of the Liguria-Provence area (Bernabeu et al. 2009; Bernabeu and Martí Oliver 2014). It has not been possible to fully confirm this first neolithisation by radiocarbon analysis, although some approximations have been made (Bernabeu and Martí Oliver 2014). With regard to the lithics, in Iberia, a number of investigations have documented two trends in the manufacture of sickles which may relate to two possible neolithisation routes (Gassin et al. 2010). Meanwhile the African via is being reconsidered as a result of the documentation of various cultural traditions related to lithic and ceramic complexes (Gibaja Bao and Carvalho 2010; García Borja et al. 2014). Additionally, the same situation has been documented for ceramic styles from the presence on the Andalusian coast and Morocco of ceramic sets with similar characteristics (García Borja et al. 2014).

In our view, certain indicators could point to this route (expansion along the Maghreb coast) being used by the first agricultural groups: (a) the existence of ceramic sets showing a direct relation to documented sets from Southern Italy (Camps 1974); (b) the presence on the eastern coast of Tunisia of obsidian coming from the same islands, such as Pantelleria, Palmarola and Lípari (Mulazzani et al. 2010; Le Bourdonnec et al. 2013) that have been also documented in mainland Italy. Both indicators suggest a connection between the Italian area and the African coast, although various authors are reluctant to accept this connection, arguing that some of these islands were uninhabited until the Bronze Age (Zilhão 2014). Unfortunately, this issue cannot be determined without a greater precision in the radiocarbon dataset on the south side of the Gibraltar Strait, although interesting advances are being made (Linstädter et al. 2012; Morales et al. 2013).

In this article, we have sought to stimulate an open debate, with many folds, sometimes due to the bias of the investigation, in others due to the explanatory frameworks applied. In any event, the objective pursued has consisted of updating the neolithisation cartography by means of updating the radiocarbon database (Table 1, dates of supplementary domestic material). The maps supplied allow us to explore general patterns in the population dynamics of the last hunter-gatherers and the early Neolithic. From the patterns reflected in the temporal intervals considered, and their variation through time, certain tendencies can be deduced which may be applied to the difficulties regarding the neolithisation process throughout the Western Mediterranean.

Two essential aspects can be drawn above all from the tendencies showed here: the different presence and uneven distribution of Mesolithic populations in moments preceding immediately the Neolithic, and the rapid impact and expansion of domestic plants and animals, especially along the Mediterranean coast and the main river valley (Ebro). We can also see how the kinds of samples being dated, and the problems linked with archaeological contexts and also laboratory procedures, introduce questions that must be considered (Wood 2015) in order to better understand the routes and pace of the Neolithic advance.

Acknowledgements This research was funded by the Spanish Ministry of Science grants HAR2012-33111 'MesoCocina: Los últimos cazarecolectores y el paradigma de la neolitización en el mediterráneo peninsular' and HAR2015-68962: EVOLPAST: Dinámicas evolutivas y patrones de variabilidad cultural de los últimos caza-recolectores y el primer neolítico en el este peninsular (circa 7000-4500 cal BC). We are grateful for the useful comments of two anonymous reviewers who have contributed strongly to improve the final version.

\section{References}

Ammerman AJ, Cavalli-Sforza LL (1984) The Neolithic transition and the genetics of population in Europe. Princeton University Press, Princeton

Arias Cabal P, Fano MA (2009) ¿Mesolítico geométrico o Mesolítico con geométricos? el caso de la región cantábrica. In: Utrilla P, Montes L (eds) El mesolítico geométrico en la Península Ibérica. Universidad de Zaragoza, Zaragoza, pp 69-92

Ascough P, Cook G, Dugmore A (2005) Methodological approaches to determining the marine radiocarbon reservoir effect. Prog Phys Geogr 29:532-547

Aura Tortosa JE, Jordá Pardo JF, García Borja P et al (2013) Una perspectiva mediterráneo sobre el proceso de neolitización. Los datos de la cueva de Nerja en el contexto de Andalucía (España). Menga 4:53-78

Baddeley A, Rubak E, Turner R (2015) Spatial point patterns: methodology and applications with R. Chapman and Hall/CRC Press

Badeley A, Turner R (2005) Spatstat: an R package for analyzing spatial point patterns. J Stat Softw 12:1-42

Balsera V, Bernabeu J, Costa Caramé M, et al (2015a) The radiocarbon chronology of southern Spain's late prehistory (5600-1000 cal BC): a comparative review.

Balsera V, Díaz-del-Río P, Gilman A et al (2015b) Approaching the demography of late prehistoric Iberia through summed calibrated date probability distributions (7000-2000 cal BC). Quat Int 386: 208-211 
Berger J-F, Guilaine J (2009) The 8200 cal BP abrupt environmental change and the Neolithic transition: a Mediterranean perspective. Quat Int 200:31-49. doi:10.1016/j.quaint.2008.05.013

Bernabeu J (2006) Una visión actual sobre el origen y difusión del Neolítico en la Península Ibérica. In: García Puchol O, Aura Tortosa JE (eds) 8.000 años de ocupación humana en la cabecera del río de Alcoi. Museu d'Alcoi, Alcoi, pp 189-211

Bernabeu J, Martí Oliver B (2014) The first agricultural groups in the Iberian Peninsula. In: Guilaine J, Manen C, Perrin T (eds) Transitions in the Mediterranean or how hunters became farmers. Éditions errance. Archives d'Écologie Préhistorique, Tolouse, pp 419-438

Bernabeu J, Molina L, Esquembre Bebia MA, et al (2009) La cerámica impresa mediterránea en el origen del Neolítico de la península Ibérica. In Collectively Authored: De Méditerranée et d'ailleurs...Mélanges offerts à Jean Guilaine. Archives d'Écologie Préhistorique, Tolouse, pp 83-95

Bernabeu J, García Puchol O, Pardo Gordó S et al (2014) Socioecological dynamics at the time of Neolithic transition in Iberia. Environ Archaeol J Hum Palaeoecol 19:214-225

Bernabeu J, Barton CM, Pardo Gordó S, Bergin SM (2015a) Modeling initial Neolithic dispersal. The first agricultural groups on West Mediterranean. Ecol Model 307:22-31

Bernabeu J, García Puchol O, Barton CM et al (2015b) Radiocarbon dates, climatic events, and social dynamics during the early Neolithic in Iberia. Quat Int. doi:10.1016/j.quaint.2015.09.020

Bicho N, Cascalheira J, Marreiros J, Pereira T (2011) The 2008-2010 excavations of Cabeço da Amoreira, Muge, Portugal. Mesolithic Miscellany 21:3-13

Binder D, Collina C, Guilbert R et al (2012) Pressure-knapping blade production in the north-western Mediterranean region during the seventh millennium cal B.C. In: Desrosiers P (ed) The emergence of pressure blade making: from origin to modern experimentation. Sringer Verlag, Heidelberg, pp 199-218

Bocquet-Appel J-P, Naji S, Vander Linden M, Kozlowski J (2012) Understanding the rates of expansion of the farming system in Europe. J Archaeol Sci 39:531-546

Camps G (1974) Les Civilisations préhistoriques de l'Afrique du Nord et du Sahara. CNRS, Paris

Carvalho AF (2009) O Mesolítico final em Portugal. In: Utrilla P, Montes L (eds) El mesolítico geométrico en la Península Ibérica. Universidad de Zaragoza, Zaragoza, pp 33-68

Cebrià i Escuer A, Fontanals i Torroja M, Martín P et al (2014) Nuevos datos para el Neolítico antiguo en el nordeste de la Península Ibérica procedentes de la Cova del Toll (Moià, Barcelona) y de la Cova de la Font Major (L'Espluga de Francolí, Tarragona). Trabajo de Prehistoria 71:134-145

Childe GV (1925) The dawn of European civilisation. Kegan Paul, Londres Clark G (1958) Blade and trapeze industries of the European Stone Age. Proc Prehist Soc 24:24-42

Collard M, Edinborough K, Shennan S, Thomas MG (2010) Radiocarbon evidence indicates that migrants introduced farming to Britain. J Archaeol Sci 37:866-870. doi:10.1016/j.jas.2009.11.016

Colledge S, Conolly J (2001) Early Neolithic agriculture in Southwest Asia and Europe: re-examining the archaeobotanical evidence. Archaeol Int 5:44-46

Contreras DA, Meadows J (2014) Summed radiocarbon calibrations as a population proxy: a critical evaluation using a realistic simulation approach. J Archaeol Sci 52:591-608. doi:10.1016/j.jas.2014.05.030

Core Team (2013) R: a language and environment for statistical computing. R Foundation for Statistical Computing, Vienna

Cortés Sánchez M, Jiménez Espejo FJ, Simón Vallejo MD et al (2012) The Mesolithic-Neolithic transition in southern Iberia. Quat Res 77: 221-234. doi:10.1016/j.yqres.2011.12.003
Cruz Berrocal M (2012) The Early Neolithic in the Iberian Peninsula and the Western Mediterranean: a review of the evidence on migration. J World Prehist 25:123-156. doi:10.1007/s10963-012-9059-9

Cubas Morera M, Fano MA (2011) Los primeros campesinos del Cantábrico: una revisión de la información disponible y de los modelos propuestos. Férvedes 7:77-86

Davison K, Dolukhanov P, Sarson GR et al (2009) Multiple sources of the European Neolithic: mathematical modelling constrained by radiocarbon dates. Quat Int 203:10-18

Díaz del Río Español P (2011) The Neolithic Argonauts of the western Mediterranean and other underdetermined hypotheses of colonial encounters. In: Bolender D (ed) Eventful archaeologies new approaches to social transformation in the archaeological record. Distinguished Monograph Series. Suny Press, New York, pp 88-99

Diggle PJ (1985) A kernel method for smoothing point process data. J R Stat Soc Series C (Appl Stat) 34(1985):138-147

Downey SS, Bocaege E, Kerig T, Edinborough K, Shennan S (2014) The Neolithic demographic transition in Europe: correlation with juvenility index supports interpretation of the summed calibrated radiocarbon date probability distribution (SCDPD) as a valid demographic proxy. PLoS One 9(8):e105730

Downey SS, Randall Haas W Jr, Shennan SJ (2016) European Neolithic societies showed early warning signals of population collapse. PNAS 113(n 55$): 9751-9756$

Drake BL, Blanco-González A, Lillios KT (2016) Regional demographic dynamics in the Neolithic transition in Iberia: results from summed calibrated date analysis. J Archaeol Method Theory. doi:10.1007/s10816-016-9286-y

Fernández López de Pablo J, Gómez Puche M (2009) Climate change and population dynamics during the Late Mesolithic and the Neolithic transition in Iberia. Documenta Praehistorica XXXVI:67-96

Fort J (2015) Demic and cultural diffusion propagated the Neolithic transition across different regions of Europe. J R Soc Interface 12:1-8

Gamble C, Davies W, Pettitt P et al (2005) The archaeological and genetic foundations of the European population during the late glacial: implications for 'agricultural thinking'. Camb Archaeol J 15:193-223

García Borja P, Salazar García DC, Martins HL, et al (2012) Dataciones radiocarbónicas de la Cova de la Sarsa (Bocairent, València). Recerques del Museu d'Alcoi 19-24.

García Borja P, Aura Tortosa JE, Jordá Pardo JF, Salazar García DC (2014) La cerámica neolítico de la Cueva de Nerja (Málaga, España): salas del Vestíbulo y la MIna. Archivo de Prehistoria Levantina XXX:81-131

García Puchol O (2005) El proceso de neolitizacion en la fachada mediterranea de la peninsula iberica. Tecnologia y tipologia de la piedra tallada. BAR International Series 1430, Oxford

García Puchol O, Aura Tortosa JE (2006) Dinámica secuencial del Mesolítico en la fachada mediterránea peninsular. In: García Puchol O, Aura Tortosa JE (eds) El Abric de la Falguera (Aloci, Alacant): 8.000 años de ocupación humana en la cabecera del río de Alcoi. Museu d'Alcoi, Alcoi, pp 137-157

García Puchol O, Molina L, Aura Tortosa JE, Bernabeu J (2009) From the Mesolithic to the Neolithic on the Mediterranean coast of the Iberian Peninsula. Global action in human context. Adapting to the Holocene in Iberia.

García Puchol O, Pardo Gordó S, Aura Tortosa JE, Jordá Pardo JF (2015) Last hunters-gatherers socioecological dynamics in Mediterranean Iberia. In: Bicho N, Detry C, Price TD, Cunha E (eds) Muge 150th: the 150th anniversary of the discovery of Mesolithic shellmiddens. Cambridge University Press, Cambridge

García Puchol O, Diez Castillo A, Pardo-Gordó, S (2016) Radiocarbono y neolitización en la Península Ibérica. In: Del Neolític a l'Edat del Bronze en el Mediterrani occidental. Estudis en Homenatge a Bernat Martí Oliver. TV SIP 119, Valencia, pp 61-73

Gassin B, Bicho NF, Bouby L et al (2010) Variabilité des techniques de récolte et traitement des céréales dans l'occident méditerranéen au 
néolitique ancie et moyen: facteurs environnementaux, économiques et sociaux. In: Beeching A, Thirault É, Vital J (eds) Économie et société à la fin de la préhistoire actualité de la recherche. Actes des 7e rencontres méridionales de Préhistoire récente tenues à Bron (Rhône), les 3 et 4 novembre 2006. Maison de l'Orient et de la Méditerranée, Lyon, pp 19-37

Gibaja Bao JF, Carvalho AF (eds) (2010) Os últimos caçadores-recolectores e as primeiras comunidades productoras do sul da Península Ibérica e do norte de Marrocos. Universidade do Algarve, Faro

Gibaja JF, Subirà M, Terradas X et al (2015) The emergence of Mesolithic cemeteries in SW Europe: insights from the El Collado (Oliva, Valencia, Spain) radiocarbon record. PLoS One 10:e0115505. doi: 10.1371/journal.pone.0115505

González-Sampériz P, Utrilla P, Mazo C et al (2009) Patterns of human occupation during the early Holocene in the Central Ebro Basin (NE Spain) in response to the 8.2 ka climatic event. Quat Res 71:121-132

Gronenborn D (2009) Climate fluctuations and trajectories to complexity in the Neolithic towards a theory. Documenta Praehistorica XXXVI: $97-110$

Guilaine J (2001) La diffusion de l'agriculture en Europe: une hypothèse arythmique. Zephyrus 53-54:267-272

Guilaine J (2014) Transitions en méditerranée ou comment des chasseurs devinsent agrculteurs. In: Manen C, Perrin T, Guilaine J (eds) La transition néolithique en méditerranée. Errance \& Archives d'écologie préhistorique, Paris, pp 9-10

Guilaine J, Manen C (2007) From Mesolithic to Early Neolithic in the western Mediterranean. In: Whittle A, Cummings V (eds) Going over: the Mesolithic-Neolithic transition in North-West Europe. Proccedings of British Academy, Oxford, pp 21-51

Hijmans RJ (2015) Raster: geographic data analysis and modeling. R package version 2.3-33

Hofmanová Z, Kreutzer S, Hellenthal G et al (2015) Early farmers from across Europe directly descended from Neolithic Aegeans. bioRxiv. doi:10.1101/032763

Isern N, Fort J, Carvalho AF et al (2014) The Neolithic transition in the Iberian Peninsula: data analysis and modeling. J Archaeol Method Theory 21:447-460

Isern N, Zilhao J, Fort J, Ammerman, A.J. (2017) Modeling the role of voyaging in the coastal spread of the Early Neolithic in the West Mediterranean. doi:10.1073/pnas.1613413114

Jiménez Guijarro J (2010) Cazadores y campesinos: la neolitización del interior de la Península Ibérica. Real Academia de Historia, Madrid

Jiménez Guijarro J, Rojas Rodríguez-Malo JM, Garrido Resino G, Perera Rodríguez J (2008) El yacimiento del Neolítico Inicial de La Paleta (Numancia de la Sagra, Toledo). In: Hernández Pérez MS, Soler Díaz JA, López Padilla JA (eds) IV Congreso del Neolítico Peninsular: 27-30 de noviembre de 2006. MARQ, Museo Arqueológico de Alicante, Alicante, pp 126-136

Jover Maestre FJ, García Atienzar G (2014) Sobre la neolitización de los grupos mesolíticos en el este de la Península Ibérica: la exclusión como posibilidad. Pyrenae 45:55-88

Juan Cabanilles J, Martí B (2011) La fase C del epopaleolitico reciente: lugar de encuentro o línea divisiora. Reflexiones en torno a la neolitización en la fachada mediterráneo peninsular. Veleia: Revista de prehistoria, historia antigua, arqueología y filología clásicas 24-35:611-628

Juan Cabanilles J, Martí Oliver B (2002) Poblamiento y procesos culturales en la península Ibérica del VII al V milenio ac. Papeles del Laboratorio de Arqueología de Valencia, Saguntum, pp 45-87

Larson G, Burger J (2013) A population genetics view of animal domestication. Trends Genet 29:197-205. doi:10.1016/j.tig.2013.01.003

Le Bourdonnec F-X, Poupeau G, Mulazzani S, Belhouchet L (2013) Origine de l'obsidienne des sites SHM-1 et SHM-12 (Hergla, Tunisie). In: Mulazzani S (ed) Le Capsien de Hergla (Tunisie) Culture, environnement et économie. Africa Magna Verlay, Franckfurt, pp 240-244
Linstädter J, Eiwanger J, Mikdad A, Weniger G-C (2012) Human occupation of Northwest Africa: a review of Middle Palaeolithic to Epipalaeolithic sites in Morocco. Quat Int 274:158-174

Manen C, Marchand G, Carvalho AF (2007) Le Néolithique ancien de la péninsule Ibérique: vers une nouvelle évaluation du mirage africain ? In: Evin J (ed) Un siècle de construction du discours scientifique en Préhistoire. Congrès préhistorique de France. Société préhistorique française, Avignon, pp 133-151

Manning K, Colledge S, Crema ER et al (2016) The cultural evolution of Neolithic Europe. EUROEVOL Dataset 1: sites, phases and radiocarbon data. J Open Archaeol Data. doi:10.5334/joad.40

Marchand G, Perrin T (2015) Why this revolution? Explaining the major technical shift in Southwestern Europe during the 7th millennium cal. BC Quat Int. doi:10.1016/j.quaint.2015.07.059

Martí Oliver B (2011) La cova de l'or (Beniarrés, Alicante). Papeles del Laboratorio de Arqueología de Valencia, Saguntum, pp 183-186

Martí Oliver B, Aura Tortosa JE, García Puchol O, Fernández-López de Pablo J (2009) El mesolítico geométrico de tipo “cocina” en el País Valenciano. In: Utrilla P, Montes L (eds) El mesolítico geométrico en la Península Ibérica. Universidad de Zaragoza, Zaragoza, pp 205-258

Martins H, Oms FX, Pereira L et al (2015) Radiocarbon dating the beginning of the Neolithic in Iberia: new results, new problems. J Mediterr Archaeol 28:105-131

Mathieson I, Lazaridis I, Rohland N et al (2015) Genome-wide patterns of selection in 230 ancient Eurasians. Nature 528:499-503

Medved I (2013) Continuity vs discontinuity: Epipaleolithic and Early Neolithic in the Mediterranean Southeast of the Iberian Peninsula. Universität zu Köln

Morales J, Pérez-Jordà G, Peña-Chocarro L et al (2013) The origins of agriculture in North-West Africa: macro-botanical remains from Epipalaeolithic and Early Neolithic levels of Ifri Oudadane (Morocco). J Archaeol Sci 40:2659-2669

Motuzaite-Matuzeviciute G, Lillie M, Telizhenko S (2015) AMS radiocarbon dating from the Neolithic of Eastern Ukraine casts doubts in existing chronologies. Radiocarbon 57:657-664

Mulazzani S, Le Bourdonnec F-X, Belhouchet L et al (2010) Obsidian from the Epipalaeolithic and Neolithic eastern Maghreb. A view from the Hergla context (Tunisia). J Archaeol Sci 37:2529-2537. doi:10.1016/j.jas.2010.05.013

Olalde I, Schroeder H, Sandoval-Velasco M et al (2015) A common genetic origin for early farmers from Mediterranean Cardial and Central European LBK cultures. Mol Biol Evol. doi:10.1093/ molbev/msv181

Olsen J, Heinemeier J, Hornstrup KM et al (2013) "Old wood" effect in radiocarbon dating of prehistoric cremated bones? J Archaeol Sci 40:30-34

Oms FX, Esteve X, Mestres i Mercadé J et al (2014) La neolitización del nordeste de la Península Ibérica: datos radiocarbónicos y culturales de los asentamientos al aire libre del Penedès. Trab Prehist 71:42-55

Pardo Gordó S, Bernabeu Aubán J, García Puchol O et al (2015) The origins of agriculture in Iberia: a computational model. Documenta Praehistorica XLII:117-131

Parnell A (2014) Bchron: radiocarbon dating, age-depth modelling, relative sea level rate estimation, and non-parametric phase modelling. $\mathrm{R}$ package version 4.1 .1

Perpinan O, Hijmans RJ (2014) rasterVis. R package version 0.31 .

Pettitt P, Zilhão J (2015) Problematizing Bayesian approaches to prehistoric chronologies. World Archaeol 47:525-542

Pinhasi R, Fort J, Ammerman AJ (2005) Tracing the origin and spread of agriculture in Europe. PLoS Biol 3:e410

Reimer PJ, Bard E, Bayliss A et al (2013) IntCal13 and Marine13 radiocarbon age calibration curves $0-50,000$ years cal BP. Radiocarbon $55: 1869-1887$ 
Rojo Guerra MA, Garrido Pena R, García-Martínez de Lagrán I (eds) (2012) El neolítico en la Península Ibérica y su contexto europeo. Cátedra, Madrid

Sabatier P, Manen C (2003) Chronique radiocarbone de la néolithisation en Méditerranée nord-occidentale. Bulletin de la Société préhistorique française:479-504

Shennan S, Downey SS, Timpson A et al (2013) Regional population collapse followed initial agriculture booms in mid-Holocene Europe. Nat Commun:1-8. doi:10.1038/ncomms3486

Soares AMM, Dias JMA (2006) Coastal upwelling and radiocarbonevidence for temporal fluctuations in ocean reservoir effect off Portugal during the Holocene. Radiocarbon 48:45-60

Surovell TA, Finley JB, Smith GM, Brantingham PJ, Kelly R (2009) Correcting temporal frequency distributions for taphonomic bias. J Archaeol Sci 36:1715-1724

Timpson A, Colledge S, Crema E et al (2014) Reconstructing regional population fluctuations in the European Neolithic using radiocarbon dates: a new case-study using an improved method. J Archaeol Sci. doi:10.1016/j.jas.2014.08.011

Timpson A, Manning K, Shennan S (2015) Inferential mistakes in population proxies: a response to Torfing's "Neolithic population and summed probability distribution of 14C-dates". J Archaeol Sci. doi:10.1016/j.jas.2015.08.01

Torfing T (2015) Neolithic population and summed probability distribution of 14Cdates. J Archaeol Sci 63:193-198. doi: 10.1016/j.jas.2015.06.004

Torregrosa Giménez P, Jover Maestre FJ, López Seguí E (2011) Benàmer (Muro de Alcoi). Mesolíticos y neolítico en tierras meridionales valencianas. Museu de Prehistòria, Valencia

Utrilla P, Montes Ramírez L, Mazo C et al (2009) El mesolítico Geométrico en Aragón. In: Utrilla P, Montes L (eds) El mesolítico geométrico en la Península Ibérica. Universidad de Zaragoza, Zaragoza, pp 131-190

Vaquero Rodríguez M, García-Argüelles P (2009) Algunas reflexiones sobre la ausencia de Mesolítico geométrico en Cataluña. In: Utrilla
P, Montes Ramírez L (eds) El mesolítico geométrico en la península Ibérica. Universidad de Zaragoza, Zaragoza, pp 191-204

Vergès Bosch JM, Allué E, Angelucci DE et al (2008) Los niveles neolíticos de la cueva de El Mirador (Sierra de Atapuerca, Buegos): nuevos datos sobre la implantación y el desarrollo de la economía agropecuaria en la submeseta norte. In: Hernández Pérez MS, Soler Díaz JA, López Padilla JA (eds) IV Congreso del Neolítico Peninsular: 27-30 de noviembre de 2006. MARQ, Museo Arqueológico de Alicante, Alicante, pp 418-427

Vicent García JM (1997) The island filter model revisited. In: Balmuth MS, Gilman Guillén A, Prados Torreira L (eds) Encounters and transformations. The Archaeology of Iberia in Transition. Sheffield Academic Press, Sheffield, pp 1-13

Weninger B, Alram-Stern E, Bauer E et al (2006) Climate forcing due to the $8200 \mathrm{cal}$ yr BP event observed at Early Neolithic sites in the eastern Mediterranean. Quat Res 66:401-420. doi:10.1016/j.yqres.2006.06.009

Wickhman H (2014) scales: scale functions for graphics. R package version 0.2.4.

Williams AN (2012) The use of summed radiocarbon probability distributions in archaeology: a review of methods. J Archaeol Sci 39: 578-589

Wood R (2015) From revolution to convention: the past, present and future of radiocarbon dating. J Archaeol Sci 56:61-72

Zilhão J (2001) Radiocarbon evidence for maritime pioneer colonization at the origins of farming in west Mediterranean Europe. Proc Natl Acad Sci 98:14180-14185

Zilhão J (2011) Time is on my side. In: Hadjikoumis A, Robinson E, Viner S (eds) The dynamics of neolithisation in Europe. Studies in honour of Andrew Sherratt. Oxbow Books, Oxford, pp 46-65

Zilhão J (2014) Early prehistoric navigation in the Westerm Mediterranean: implications for the Neolithic transition in Iberia and the Maghreb. Eurasian Prehistory 11(1-2):185-200 